\title{
Vidgram Sebagai Sarana Media Dakwah
}

\author{
Taqdirul Alim Yanis ${ }^{1 *}$, Mukhlis Aliyudin ${ }^{1}$, Asep Shodiqin ${ }^{2}$ \\ 1,2Jurusan Komunikasi dan Penyiaran Islam, Fakultas Dakwah dan Komunikasi, UIN Sunan \\ Gunung Djati, Bandung \\ *Email : alimtaqdirul@gmail.com
}

\begin{abstract}
ABSTRAK
Tulisan ini bertujuan untuk mengetahui bagaimana penggunaan vidgram sebagai sarana media dakwah yang mana didalamnya terdapat pula pembahasan mengenai materi dakwah, serta kriteria vidgram pada akun instagram pelangiislam. Metode yang digunakan adalah metode penelitian deskriptif terhadap akun instagram @pelangiislam. Hasil penelitian ditemukan bahwa akun instagram@pelangiislam menggunakan fitur vidgram untuk menyampaikan pesan dakwah dengan jenis video berdurasi maksimal 60 detik, materi yang disampaikan dikategorikan terhadap 3 materi pembahasan, materi akidah, materi akhlak dan materi syari'ah serta kriteria vidgram sebagai sarana media dakwah pada akun instagram@pelangiislam terdapat lima poin, lemah lembut dalam menyampaikan, mempermudah tidak mempersulit, memberikan kesadaran, tidak provokatif dan memiliki pendasaran yang kuat.
\end{abstract}

Kata Kunci : Dakwah; Vidgram; Media Sosial; Instagram.

\section{ABSTRACT}

This paper aims to find out how to use vidgram as a means of da'wah media in which there is also a discussion on the material of da'wah, as well as the vidgram criteria on the Pelangiislam Instagram account. The method used is a descriptive research method of the Islamic rainbow account. The results of the study found that the Pelangiislam Instagram account uses the vidgram feature to deliver propaganda messages with a video type of a maximum duration of 60 seconds, the material delivered is categorized into 3 discussion material, aqidab material, moral material and shari'ah material and vidgram criteria as a means of propaganda media on the account rainbow Islamic instagram there are five points, gentle in conveying, making it easier not to complicate, giving awareness, not provocative and having a strong foundation.

Keywords: Da'wab; Vidgram; Media Social; Instagram. 


\section{PENDAHULUAN}

Jika kita memperhatikan media sosial saat ini, kita menemukan bearagam reaksi dari khalayak dalam mengambil sikap terhadap perkembangan teknologi yang ada. Ada yang memanfaatkan teknologi untuk membentuk komunitas belajar online, membuat postingan, membuat berbagai macam grup, saling bertukar informasi hingga berdakwah di media sosial.

Dakwah pada dasarnya adalah menyampaikan ajaran islam kepada masyarakat luas. Hakikat dakwah itu sendiri adalah upaya untuk menumbuhkan kecenderungan dan ketertarikan menyerukan ajaran agama islam kepada seseorang serta pada apa yang diserukan. Didalam Al-Qur'an terdapat berbagai macam ayat yang menjelaskan terkait perintah berdakwah yang mana berdakwah merupakan salah satu kegiatan mulia yang telah dicontohkan oleh Rasulullah SAW serta para sahabatnya.

Dakwah yang dulu terbatas hanya dilakukan di majelis - majelis pengajian, kini sudah masuk ke dalam platform baru yang kita sebut media sosial. Fenomena ini sedikit banyak mengubah persepsi masyarakat yang mengatakan bahwa dakwah hanya terbatas di tempat ibadah saja yang dilakukan oleh penceramah. Kini, semua orang bisa berdakwah dengan platform media sosial mereka masing masing.

Populasi penduduk Indonesia saat ini sudah mencapai angka 262 juta orang. Dilansir dari laporan teranyar asosiasi penyelenggara jasa internet Indonesia (APJII) lebih dari 50 persen atau sekitar 143 juta orang Indonesia telah terhubung di jaringan internet. Mayoritas pengguna internet sebanyak 72,41 persen masih dari kalangan masyarakat Urban. Pemanfaatan internet bukan hanya untuk berkomunikasi tapi juga untuk membeli barang, belajar dan mengajar hingga berbisnis. Dari angka 143 juta orang Indonesia yang menggunakan internet tercatat pula sekitar 120 juta orang yang aktif berselancar menggunakan media sosial yang salah satunya adalah media sosial instagram, yang mana instagram merupakan salah satu media sosial yang diminati oleh kalangan masyarakat Indonesia dengan jumlah pengguna berada di kisaran 53 juta pengguna.

Instagram adalah salah satu sarana yang dapat digunakan sebagai media dakwah. Instagram merupakan aplikasi berbagi foto, video yang memungkinkan mengambil gambar, menerapkan filter digital, dan membagikannya ke berbagai layanan jejaring sosial, termasuk milik instagram sendiri. Satu fitur yang menarik sekaligus yang menjadi objek penelitian kali ini yaitu terkait fitur video gram yang memungkinkan para pengguna instagram dapat membagikan video dengan durasi yang ditentukan kepada pengguna lainnya.

Video Gram (Vidgram) merupakan salah satu dari sekian banyak fitur 
Taqdirul. A.Y, M. Aliyudin, Shodiqin. A.

yang digunakan oleh para pengguna instagram. Fitur merupakan suatu aspek yang memiliki keunggulan tersendiri yang menjadi daya tarik dari suatu benda tersebut, maka dari itu fitur vidgram dapat diartikan sebagai aspek yang memiliki keunggulan berupa video berdurasi maksimal 60 detik yang dapat diposting disetiap akun pengguna Instagram dengan ketentuan-ketentuan yang ada.

Berbicara mengenai vidgram, maka ada kaitannya dengan yang dinamakan media dakwah, yang mana hal ini pun menjadi pusat konsentrasi dalam penelitian ini. Menurut Moh. Ali Aziz dalam bukunya yang berjudul Ilmu Dakwah (2004:120), media dakwah adalah alat yang dipergunakan untuk menyampaikan materi dakwah (ajaran islam) kepada mad'u (objek dakwah). Dengan perkembangan zaman serta teknologi saat ini, aktivitas dakwah diharapkan dapat berjalan dengan sebaik mungkin, karena dengan adanya teknologi modern para penggiat dakwah seharusnya dapat memaksimalkan hal ini dengan sebaik mungkin. Hal ini bertujuan agar dakwah itu sendiri dapat tercapai semaksimal mungkin. Untuk mencapai dalam pemaksimalkan media dakwah ini para penggiat dakwah harus lebih mengetahui kapasitas ilmu yang ada didalam dirinya, sehingga dengan itu para pelaku dakwah dapat belajar serta memahami lebih detail lagi terkait dakwah serta media nya saat ini. Jika ini terlaksana maka dapat meminimalisir kesalahan dalam berdakwah di media ini.

Kemajuan dalam bidang teknologi khususnya pada aspek media sosial dapat mempermudah dalam menyampaikan pesan dakwah dan juga menjadikan sebuah tantangan bagi seorang $d a^{\prime} i$, yang mana dewasa ini da'i dituntut lebih cermat dalam menggunakan media sosial sehingga dapat menyampaikan pesan dakwah kepada mad'u yang berada jauh dari jangkauan.

Akun instagram@pelangiislam merupakan salah satu dari berbagai akun instagram yang menyajikan konten-konten terkait kajian keislaman. Dengan pengemasan konten dakwah yang baik, akun pelangiislam mampu menarik perhatian pengguna instagram untuk melihat serta mendengarkan pesan dakwah yang disampaikan dengan menggunakan fitur vidgram, tercatat hingga saat ini akun pelangiislam telah memiliki ratusan ribu followers.

Segmentasi yang instagram Pelangiislam ini lebih besarnya adalah kalangan remaja serta anak muda, sehingga akun ini dengan sengaja mengemas dakwah melalui fitur vidgram tersebut dengan semenarik dan semodern mungkin, hingga sasaran dakwah yang dituju dapat menerima serta memahami pesan dakwah yang disampaikan.

Masalah yang diangkat dalam penelitian ini yaitu mengenai bagaimana penggunaan vidgram sebagai sarana media dakwah oleh akun instagram @pelangiislam, materi apa saja yang disampaikan serta bagaimana kriteria vidgram sebagai sarana media dakwah oleh akun instagram pelangiislam. Dalam menyelesaikan masalah yang diangkat, penulis menggunakan teori media dari Marshall McLuhan sebagai acuan dalam penelitian ini yaitu berupa penjelasan 
bahwa media yang dipilih sama pentingnya dengan pesan itu sendiri.

\section{LANDASAN TEORITIS}

Bagi masyarakat, kata "dakwah" tampaknya bukan lagi sesuatu yang asing, secara sederhana dakwah dapat ditemui dalam banyak bentuk, ceramah, pengajian, diskusi, tabligh akbar, bahkan dalam obrolan-obrolan santai seputar diskusi terkait ajaran agama islam.

Secara etimologi, dakwah berasal dari kata da'a, yad'u, da'watan yang bermakna seruan, panggilan, undangan, do'a (Tata Sukayat, 2015: 7). Didalam Al-Qur'an terdapat cukup banyak pengulangan kata dakwah dan devirasinya sebanyak 321 kali. Pengulangan kata dakwah dan aktivitas yang serupa dengannya dalam Al-Qur'an mengisyaratkan bahwa dakwah merupakan komponen penting dalam kehidupan manusia. Dakwah memiliki sejumlah istilah yang biasanya digunakan dalam konteks tertentu yang lebih spesifik. Oleh karena itu, secara praktis term dakwah lebih dipandang sebagai term genetik yang sesungguhnya dapat lebih dipahami melalui sisi-sisi yang lebih spesifik (Moch. Fkahruroji, 2017: 2)

Secara terminologi, dakwah merupakan suatu proses mengajak, mendorong, memotivasi manusia untuk berbuat baik, mengikuti petunjuk Allah, menyuruh mengerjakan kebaikan dan melarang mengerjakan kejelekan agar dia bahagia didunia dan akhirat (Saerozi, 2013: 9). Maka dari itu sudah menjadi kewajiban bagia setiap muslim dalam hal amar ma'ruf nabyi munkar.

Sementara dengan pendekatan proses, syukriadi sambas lebih menjelaskan dakwah sebagai proses tansmisi, trasnformasi, dan internalisasi ajaran islam dengan menggunakan metode, media, dan untuk mencapai tujuan tertentu. Sambas lebih melihat dakwah sebagai sebuah proses yang panjang dari pada hanya berbicara tentang tujuan pelaksanaan dakwah itu sendiri. Dalam definisi yang ditawarkannya, sambas mengungkapkan bahwa proses penyampaian dakwah lebih ditekankan pada aspek pengunaan metode, media, dan pesan yang disesuaikan dengan situasi serta kondisi mad'u dilapangan (Moch. Fakhruroji, 2017:2).

Lebih spesifik, Enjang dan Aliyudin (2019: 12) mengungkapkan bahwa kegiatan dakwah merupakan proses mengajak manusia kepada al-islam yang dilakukan dengan lisan ataupun tulisan juga dapat dilakukan dengan perbuatan. Lebih jauh, dakwah juga dapat dilakukan dengan mengorganisasi serta mengelola kegiatan dalam bentuk lembaga-lembaga islam sebagai lembaga dakwah yang melakukan sistemisasi tindakan, koordinasi, dan integrasi program dengan sumber daya yang tersedia untuk mencapai sasaran perubahan yang dituju.

Melaksanakan dakwah atau berdakwah merupakan sebuah keharusan bagi setiap muslim. Sebagaimana yang Allah perintahkan didalam Al-Qur'an, dan 
Taqdirul. A.Y, M. Aliyudin, Shodiqin. A.

juga sebagaimana yang Rasulullah Saw contohkan pada zamannya. Terdapat berbagai ayat didalam Al-Qur'an yang menjelaskan mengenai anjuran serta keharusan setiap muslim untuk berdakwah, sebagaimana dalam firman Allah surat Ali-Imran ayat 104:

"Dan hendaklah diantara kamu ada segolongan orang yang menyeru kepada kebajikan, menyuruh berbuat (berbuat) yang makhruf, dan mencegah dari yang munkar. Dan mereka itulah orang-orang yang beruntung (Kementrian Agama RI 2011:63).

Allah Swt juga berfirman didalam Al-Qur'an surat An-Nahl ayat 125 :

"Serulah (manusia) kepada jalan tuhanmu dengan hikmahdan pengajaran yang baik, dan berdebatlah dengan mereka dengan cara yang baik. Sesungguhnya tuhanmu, dialah yang lebih mengetahui siapa yang sesat dijalan-Nya dan dialah yang lebih mengetahui siapa yang mendapat petunjuk (Kementrian Agama RI 2011:63).

Kata $u$ d'u yang diterjemahkan dengan seruan dan ajakan adalah fi'il amr yang menurut kaidah ushul fiqh setiap fi'il amr adalah perintah dan perintah adalah wajib dan harus dilaksanakan, selama tidak ada dalil yang memalingkannya dari kewajiban itu kepada sunnah atau hukum lain. Jadi, melaksanakan dakwah hukumnya wajib karena tidak ada dalil-dalil yang memalingkannya dari kewajiban itu dan hal ini disepakati oleh para ulama (Samsul Munir Amin, 2009:51).

Hanya saja terdapat perbedaan pendapat ulama tentang status kewajiban itu apakah fardlu ain atau fardlu kifayah. Dengan demikian dakwah bisa menjadi fardlu `ain apabila di suatu tempat tidak ada seorang pun yang melakukan dakwah dan dakwah bisa menjadi fardlu kifayah apabila di suatu tempat sudah ada orang yang melakukan dakwah dan orang itu memiliki kemampuan serta keahlian dalam berdakwah. Demikian juga, ketika jumlah da'I masih sedikit, sementara tingkat kemungkaran sangat tinggi dan kebodohan merajalela, maka dakwah menjadi wajib ain bagi setiap individu sesuai dengan kemampuannya (Awaludin Pimay, 2005: 34).

Perintah dakwah tidak hanya ditunjukan kepada umat islam secara umum yang terkandung dalam surat Ali-Imran ayat 104, akan tetapi ada pula perintah dakwah yang ditekankan kepada seriap individu yang mampu untuk merubah kemungkaran, sebagaimana yang tercantum dalam hadist :

"barang siapa diantara kamu melihat kemungkaran, hendaklah merubahnya dengan tangan, jika tidak mampu dengan lisan, jika tidak mampu dengan hati dan itulah selemah-lemahnya iman" (HR.Admad) (Ali Aziz, 1998:2).

Penekanan dakwah pada hadist ini merupakan cara bagi setiap individu muslim untuuk melakukan dakwah, yang mana apabila seseorang melihat adanya 
kemungkaran, maka sudah seharusnya sebagai seorang pribadi muslim yang baik harus merubahnya, yang pertama ialah menggunakan tangan nya. Tangan disini bukan semerta merta dengan kekerasan akan tetapi lebih kepada yang dinamakan dengan kekuasaan, apabila seseorang memiliki otoritas dan dapat merubah kemungkaran yang ada disana, maka rubahlah dengan menggunakan otoritasnya tersebut.

Yang kedua dalam hadist tersebut, apabila tidak dapat merubah suatau kemungkaran dengan tangan, maka yang cara yang kedua yaitu dengan lisan, hal ini sebagaimana yang dinamakan dengan nasihat, apabila seseorang tidak memiliki otoritas untuk bertindak merubah kemungkaran, maka nasihatilah orang yang melakukan kemungkaran tersebut, dengan harapan orang itu mendapatkan pengertian lebih dan meninggalkan hal-hal yang bersifat kemungkaran tersebut.

Lantas cara yang terakhir ketika tidak ada lagi yang bisa dilakukan, maka salah satu caranya yaitu dengan hati, hati disini dapat diartikan dengan sebuah do'a, yang mana do'a menjadi harapan terakhir seseorang untuk merubah kemungkaran dengan mengharap pertolongan Allah SWT. Akan tetapi dalam hasdist ini cara yang terakhir ditutup dengan kalimat "demikian itu adalah selemah-lemahnya iman”, yang mana dimaksudkan cara ini adalah cara terakhir yang bisa seseorang tempuh dalam jalan dakwahnya apabila dengan tangan dan lisan tidak dapat merubah suatu kemungkaran.

Dengan demikian dari penjelasan diatas dapat diketahui bahwa salah satu kewajiban umat muslim didunia ini adalah berdakwah sebagaimana yang telah Allah perintahkan dalam Al-Quran dan juga sebagaimana yang Rasulullah Saw telah contohkan pada zamannya untuk dipahami serta diikuti oleh umatnya sebagai salah satu ibadah serta kewajiban yang bisa membawa umatnya ke tempat yang diridhai oleh Allah Swt.

Dakwah merupakan suatu rangkaian kegiatan yang didalamnya melibatkan unsur-unsur tertentu dalam dalam membentuk sebuah system yang saling berhubungan secara sistematis dan fungsional untuk mencapai tujuan dakwah. Unsur dakwah yang dimaksud adalah unsur yang pokok dalam pelaksanaan dakwah, yang secara minimal harus ada. Unsur-unsur dakwah yang pokok tersebut yaitu : Da'i (Subjek Dakwah), Mad'u (Objek Dakwah),maudu' (Materi Dakwah), Wasilah (Media Dakwah), Uslub (Metode Dakwah).

Empat belas abad berlalu sejak zaman Rasulullah SAW, aktifitas dakwah terus menerus berlangsung di tengah perubahan dan kebudayaan di masyarakat. Aktifitas dakwah tetap hadir dengan pendekatan-pendekatan yang baru dengan mengikuti perubahan zaman. Seiring dengan itu dakwah muncul dan berevolusi dengan beragam bentuk yang baru dan berubah-ubah sesuai dengan zaman dan manusianya (Fakhruroji, 2017: 10).

Dalam buku karangan Fakhruroji (2017:10), Nurcholis majid mengatakan 
Taqdirul. A.Y, M. Aliyudin, Shodiqin. A.

bahwa dakwah berisikan ide progresif, artinya sebuah proses yang terus menerus berubah baik menjadi lebih baik dalam mewujudkan dakwah itu sendiri. Salah satunya adalah perubahan media dakwah dari zaman ke zaman . dahulu media dakwah hanya mengandalkan lisan ke lisan, lalu dari surat ke surat. Setelah muncul media modern, media dakwah yang awalnya tradisional berubah menjadi media yang modern, seperti TV, Radio hingga media yang berbasis internet, Meskipun dakwah tidak meninggalkan media-media terdahulu. Jika dakwah tidak mengikuti perubahan zaman antara lain dalam penggunaan media modern untuk sarananya, maka dakwah akan sulit diterima oleh masyarakat lusa yang bersifat multicultural yang mana dalam kesehariannya menggunakan media sosial.

Keragaman multimedia saat ini khususnya media sosial memungkinkan dakwah untuk masuk keruang kehidupan dan kegiatan manusia, dari mulai pribadi hingga ruang public. Dakwah menggunakan multimedia merupakan kegiatan dakwah yang tanpa batas waktu. Selain tidak terbatas waktu, dakwah multimedia pun tidak terbatas tempat, semua manusia yang berada dibelahan dunia manapun dapat merasakan kehadiran dakwah islam. Dengan dakwah yang intens, dakwah menggunakan multimedia memberikan kontribusi yang sangat penting dalam dunia dakwah untuk mencapai tujuan dakwah (Solahudin, 2011: 407).

Media sering dikenal sebagai alat komunikasi. Media mengalami perkembangan dari media lama (old media) dan media baru (new media). Salah satu dari media baru yaitu media sosial. Adapun kata "sosial" dalam media sosial secara teori semestinya didekati oleh ranah sosiologi. Bahkan, dalam teori sosiologi disebutkan bahwa media pada dasarnya adalah sosial karena media merupakan bagian dari masyarakat yang dipresentasikan dalam bentuk perangkat teknologi yang digunakan. Berdasarkan teori-teori sosial yang dikembangkan oleh Durkheim, Weber, Tonnies maupun Marx, dapat disimpulkan bahwa media sosial bias dilihat dari perkembangan bagaimana hubungan individu dengan perangkat media (Rulli Nasrullah, 2017:6,8).

Media sosial adalah media internet yang memungkinkan penggunanya mempresentasikan diri, berkomunikasi, bekerja, maupun berinteraksi dengan pengguna lain dan membentuk ikatan sosial secara virtual (Nasrullah, 2015: 11).

Salah satu bentuk media sosial adalah instagram, kata instagram berasal dari kata Instan dan Telegram. Instan memiliki arti foto isntan yang berasal dari kamera polaroid, sedangkan telegram memiliki arti alat untuk mengirimkan pesan kepada seseorang. Jadi secara garis besar dapat disimpulkan bahwa instagram adalah aplikasi berjenis media sosial untuk berbagi pesan melalui sebuah foto penggunanya. Selain untuk berbagi, instagram membuat para penggunanya lebih kreatif. Dikarenakan instagram memiliki fitur yang memungkinkan penggunanya membuat foto menjadi lebih indah dan artistik (Atmoko, 2012: 10). 
Melihat perkembangan penggunaan media sosial khususnya instagram di Indonesia, maka instagram tidak hanya digunakan untuk ajang berbagi foto, akan tetapi jauh kepada hal yang lebih bermanfaat, salah satunya untuk berdakwah. Hal ini menjadi sebuah konsentrasi besar bagi para pelaku dakwah, karena dengan berkembangnya media sosial para pelaku dakwah dituntut lebih cermat dalam memaksimalkan pemanfaatan media sosial sebagai sarana media dakwah, salah satunya dengan aplikasi Instagram dan berbagai fitur didalamnya yang dapat menunjang kesuksesan dalam berdakwah itu sendiri.

\section{HASIL DAN PEMBAHASAN}

Berdakwah menggunakan fitur vidgram oleh akun instagram@pelangiislam terbilang sederhana namun berkualitas, setelah melewati tahapan pemilihan video dakwah, da'i serta materi dakwahnya, akun pelangiislam memilih serta memilah bagian terpenting pada video kajian dakwah tersebut sehingga menjadi sebuah video gram yang berdurasi maksimal 60 detik, dengan menambahkan berbagai komponen seperti logo, thumbnail serta tanpa menghilangkan sumber awalnya.

Materi dakwah yang disajikan merupakan sebuah produksi ulang dari materi yg telah melewati beberapa proses tahapan, serta dapat dikategorikan kepada 3 materi pembahasan yaitu materi akidah, akhlak dan syari'ah, tidak ada penekanan terhadap salah satu materi, karena dirasa ketiga materi tersebut penting untuk disampaikan.

Pada proses penyampaian dakwahnya, akun pelangiislam memiliki kriteria tersendiri terkait vidgram sebagai sarana media dakwah yaitu terdapat 5 poin: lemah lembut dalam menyampaikan, mempermudah tidak mempersulit, memberikan kesadaran, tidak provokatif dan memiliki pendasaran yang kuat.

\section{Penggunaan Vidgram Sebagai Sarana Media Dakwah}

Fitur vidgram merupakan salah satu fitur terpopuler yang dimiliki oleh instagram. Dengan memaksimalkan kualitas video tersebut, instagram membatasi durasi potingan dari vidgram tersebut yaitu maksimal 60 detik. Akun instgaram@pelangiislam pada awalnya menggunakan fitur vidgram sebatas hanya untuk membagikan video tentang kajian ilmu keislaman, tanpa adanya perancangan konsep baik tema, materi dakwah hingga pengemasan dakwah vidgram itu sendiri. Pada tanggal 1 september 2017 merupakan awal mula akun Pelangiislam memposting video terkait kajian keislaman, postingan pertamanya yaitu terkait Hijrah karena wanita yang mana materi tersebut disampaikan oleh Ustadz Syafiq Riza Basallamah.

Penggunaan fitur vidgram oleh akun pelangiislam sendiri pada awalnya dapat dibilang sangat sederhana, tanpa adanya ketentuan serta kreatifitas pada 
Taqdirul. A.Y, M. Aliyudin, Shodiqin. A.

pengemasan video gram nya tersebut. Hanya melalui tahap pemilihan video kajian dakwah keislaman lalu mengambil part terpenting pada dakwah tersebut lalu memberikan thumbnail sebagai salah satu inovasinya pada saat itu. Pengemasan isi pesan dakwah pada awal-awal terbentuknya akun tersebutpun tergolong biasa saja. Akan tetapi, lambat laun mulai bermunculan nya komentarkomentar positif terkait akun instagram pelangiislam yang memanfaatkan instagram sebagai media dakwahnya. Tidak hanya dari sisi komentar yang ada, mulai bertambahnya para pengikut atau followers akun tersebut secara signifikan, hal inilah yang menjadikan akun pelangiislam mulai merancang konsep agar kajian dakwah keislaman dapat lebih menarik, sehingga dapat dipahami oleh para pengikutnya yang mendengarkan nya.

Konten-konten vidgram yang diposting oleh akun instagram @ pelangiislam merupakan hasil dari proses pemilahan dan pemilihan, sehingga kajian keislaman yang disampaikan sesuai dengan situasi dan kondisi yang sedang beredar dimasyarakat. Ditakutkan apabila kajian dakwah keislaman yang diposting tidak tepat dengan kondisi yang berada dikalangan masyarakat ini, malah mengakibatkan adanya perseteruan oleh para pengguna dikolom komentar dan adanya sikap saling menyalahi satu sama lain, sehingga tujuan dakwah yang diharapkan tidak dapat tercapai atau berada di koridor yang salah.

Penulis sendiri mengajukan pertanyaan kepada beberapa informan yang merupakan pengikut atau followers akun pelangiislam ini terkait apakah pesan yang disampaikan melalui fitur vidgram ini oleh akun tersebut dapat dipahami dengan jelas

Seorang informan bernama Muhammad Hasbi yaitu merupakan pengikut akun pelangiislam yang telah cukup lama menjadi pengikut akun tersebut, menurutnya :

Saya melihat adanya pengemasan dakwah yang baik dari waktu ke waktu pada instagram tersebut, yang membuat saya dapat memahami setiap pesan dakwah yang disampaikan melalui berbagai ustadz pilihan (Wawancara, 14 Juni 2019).

Informan lainpun turut memberikan tanggapan nya terkait dakwah yang disampaikan oleh akun tersebut, salah satunya adalah Imam, ia mengatakan :

tidak ada hal yang perlu digaris bawahi pada bagian pengemasan dakwahnya, akan tetapi bagi saya yang amat disayangkan, kurang maksimalnya interaksi dari pemilik akun terhadap para pengikutnya ataupun yang sekedar singgah dipostingan nya, yang mana terkadang ada pengguna yang melontarkan pertanyaan seputar kajian ataupun seputar hal yang lain, tidak mendapatkan tanggapan dari pemilik akun tersebut salah satunya dikolom komentar,

Imam menegaskan :

Alangkah baiknya ada tanggapan yang dilontarkan secara maksimal 
terhadap para pengguna yang menaruh komentar pada postingan tersebut, sehinngga kesan yang ditimbulkan terhadap akun Pelangiislam dianggap baik (Wawancara, 14 Juni 2019).

Penggunaan vidgram sebagai sarana media dakwah oleh akun instagram @ pelangiislam sedikit besarnya terbilang berhasil, karena berdakwah dimedia sosial khususnya instagram keberhasilan dakwah itu sendiri dapat dilihat dari aktifitas para pengikutnya, pada akun instagram tersebut terlihat adanya sikap responship para pengikutnya, baik dikolom komentar ataupun melakukan aktifitas respost, walaupun memang ada pula bebarapa komentar yang dianggap menyanggah terkait persoalan materi dakwah yang disampaiakn, akan tetapi sejauh ini kolom komentar sebagian besar berisi tanggapan-tanggapan yang baik serta memotivasi para pengguna lainnya.

Dakwah melalui fitur vidgram sudah menjadi inovasi, lebih tepatnya menjadi keharusan bagi para pelaku dakwah atau da'i yang ingin melanjutkan aktifitas dakwahnya di instagram. Fitur ini menjadikan para pengguna nya mudah melakukan kegiatan apapun khususnya dakwah berupa video dengan durasi maksimal 60 detik, baik video dengan produksi sendiri, pengumpulan video kajian keislaman lalu melewati tahap edit maupun hanya sekedar re-posting konten orang lain.

Tidak heran kalau internet begitu dan sering kali dijadikan sumber mencari bahan dakwah da'i, juga sebagai media menyebarkan pesan-pesan dakwahnya. Karena internet memiliki beberapa karakteristik. Dan karakteristik internet yang bersifat interaktif telah mampu menjelma menjadi media interaksi sosial yang terbuka dan bersifat timbal balik. Adanya keterpaduan diantara peran the author (pihak yang memproduksi pesan) dan the reader (pihak) yang menerima dan membaca pesan (Fakhruroji, 2011:39).

Kebutuhan masyarakat dan pengguna instagram terkait kajian dakwah keislaman yang praktis, membuat akun pelangiislam menaruh perhatian lebih dan menjadikan dakwah vidgram ini sebagai fokus untuk meraih tujuan dakwah itu sendiri. Dengan berkeyakinan bahwa manusia yang baik adalah manusia yang bermanfaat bagi orang lain, akun dakwah pelangiislam mempertahankan dakwah menggunakan media ini dengan besar harapan masyarakat diamanapun dapat mengakses kajian terkait dakwah keislaman tanpa terhalang tempat, jarak dan waktu. Sehingga pada zaman yang super modern ini, ilmu keislaman tidak menjadi hal yang tabu, dan dapat menyelamatkan manusia dikahirat kelak sebagai akhir dari pertanggung jawaban hidupnya didunia. Dengan begitu sebagaimana yang diharapkan oleh seluruh umat agar diberikan tempat kembali yang terbaik, yaitu sebaik-baiknya tempat kembali yang diridhai oleh Allah SWT.

\section{Materi Dakwah Akun Instagram Pelangiislam}


Taqdirul. A.Y, M. Aliyudin, Shodiqin. A.

Materi dakwah (maddah) adalah pesan dakwah yang dibawakan serta disampaikan oleh seorang pelaku dakwah (da'i) kepada khalayak / masyarakat luas (mad'u). Materi dakwah merupakan salah satu komponen serta unsur yang tidak boleh hilang saat melakukan aktifitas dakwah, karena materi dakwah yang tepat dapat menjadi penentu pencapaian tujuan dakwah, apakah diterima atau tidak oleh masyarakat (mad'u).

Pada umumnya materi dakwah yang disajikan oleh akun pelangiislam merupakan sebuah produksi ulang dari materi yang telah melewati proses / tahap editing tanpa menghilangkan sumber awal materi tersebut. Sebagai contoh, materi dakwah yang ia dapat berdurasi 1 jam, maka karena media yang digunakan berbeda, akun@pelangiislam memotong serta memilah poin-poin penting yang akan disampaikan dan menambahkan berbagai komponen, seperti thumbnal, tagar, caption sebagai pelengkap dan penjelas pesan dakwah tersebut.

Materi dakwah yang disampaikan oleh akun pelangiislam berupa videogram berdurasi 60 detik yang dikemas menggunakan gaya akun tersebut. Videogram yang disampaikan dapat dikategorikan kepada 3 materi bahasan, sebagai berikut :

Materi dakwah (maddah) adalah pesan dakwah yang dibawakan serta disampaikan oleh seorang pelaku dakwah (da'i) kepada khalayak / masyarakat luas (mad'u). Materi dakwah merupakan salah satu komponen serta unsur yang tidak boleh hilang saat melakukan aktifitas dakwah, karena materi dakwah yang tepat dapat menjadi penentu pencapaian tujuan dakwah, apakah diterima atau tidak oleh masyarakat (mad'u).

Pada umumnya materi dakwah yang disajikan oleh akun pelangiislam merupakan sebuah produksi ulang dari materi yang telah melewati proses / tahap editing tanpa menghilangkan sumber awal materi tersebut. Sebagai contoh, materi dakwah yang ia dapat berduaasi 1 jam, maka karena media yang digunakan berbeda, akun pelangiislam memotong serta memilah poin-poin penting yang akan disampaikan dan menambahkan berbagai komponen, seperti thumbnail, tagar, caption sebagai pelengkap dan penjelas pesan dakwah tersebut.

Materi dakwah yang disampaikan oleh akun pelangiislam berupa videogram berdurasi 60 detik yang dikemas menggunakan gaya akun tersebut. Videogram yang disampaikan dapat dikategorikan kepada 3 materi bahasan: Akidah, Akhlak, Syari'ah.

Aqidah merupakan makna kokoh yang terdapat didalam agama, pada dasarnya aqidah merupakan bahasan tentang keyakinan, keteguhan serta pedoman yang dimiliki setiap manusia dalam bearagama. Dalam islam sendiri aqidah berarti iman yang bersumber dari apa yang diturunkan oleh Allah SWT kepada umatnya (Al-Qur'an) dan apa yang dicontohkan oleh Rasul-Nya (Sunnah / Hadist). Akun pelangiislam berpendapat bahwasannya materi tentang segala sesuatu yang berkaitan dengan aqidah, amat perlu rasanya disampaikan, karena 
aqidah merupakan pondasi awal seseorang dalam beragama dan meyakini ajaran serta penciptanya. Akun pelangiislam sendiri telah membagikan begitu banyak postingan yang berkaitan serta membahas tentang segala aspek dalam aqidah itu sendiri, diantaranya :

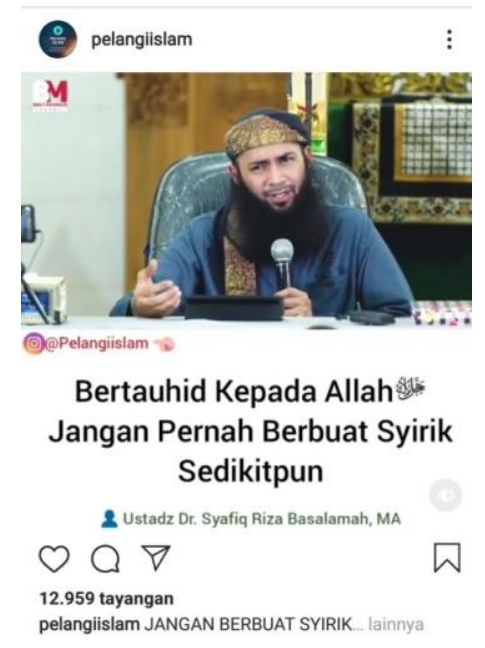

Sumber: Instagram @Pelangiislam

Gambar 1. Bertauhid Kepada Allah

Ustadz Dr. Syafiq Riza Basalamah, MA dalam ceramahnya mengingatkan bahwa jangan sekali kali kita berbuat syirik karena sesungguhnya dosa syirik tidak akan diampuni oleh Allah SWT. "sesungguhnya Allah tidak akan mengampuni dosa syirik kepadanya, dan dia akan mengampuni dosa lain yang berada dibawah tingkatan syirik bagi siapa yang dikehendaki oleh-Nya"

Allah SW'T juga mengharamkan shurga dimasuki oleh orang-orang yang berbuat syirik. Sebagaimana firman-Nya dalam QS. Al-Maidah ayat 72 yang artinya : "sesungguhnya barangsiapa yang mempersekutukan Allah maka sesungguhnya Allah telah mengharamkan shurga baginya dan tempat kembalinya adalah neraka, dan tiada seorang penolongpun bagi orang-orang dzalim tersebut".

Sesuai dengan firman Allah SWT diatas, kita senantiasa harus menjaga diri kita dan membekali diri kita dengan segala ilmu pengetahuan agama, agar kita terhindah dari perbuatan yang menyekutukan Allah SWT. 


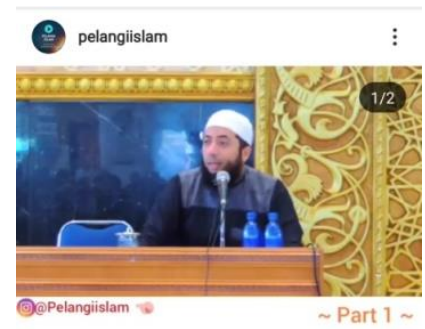

Allah Berada Diatas Langit

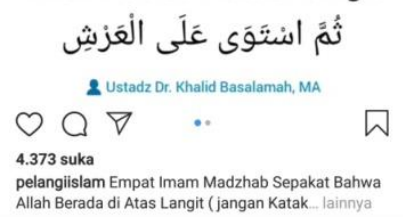

Sumber: Instagram @Pelangiislam

\section{Gambar 2. Allah SW'T Berada Di atas Langit}

Ustadz Dr. Khalid Basalamah, MA menjelaskan bahwa empat Imam Madzhab sepakat bahwa Allah berada di atas langit ( jangan katakan Allah ada dimana mana).

Sifat istiwa adalah salah satu sifat Allah yang telah Allah Ta'ala tetapkan untuk diri-Nya dalam tujuh ayat Al-Qur'an, yaitu Al-A'raf : 54, Yunus : 3, ArRa'd : 2, Al-Furqan : 59, As-Sajdah : 4 dan Al-Hadid : 4. Beliau menegaskan pula bahwa Imam Asy Syafi'I yang mana menjadi rujukan mayoritas kaum muslimin di Indonesia dalam masalah fiqih pula meyakini bahwa Allah berada diatas langit.

Akhlak merupakan suatu sifat yang tertanam didalam diri manusia, bisa bernilai baik maupun buruk. Akhlak sendiri tidak selalu identik dengan pengetahuan, ucapan ataupun perbuatan orang yang bisa mengetahui banyak tentang baik buruknya akhlak, yang mana belum tentu hal ini didukung oleh keluhuran akhlak itu sendiri. Dengan kata lain akhlak merupakan sifat-sifat bawaan manusia sejak lahir yang tertanam dalam jiwanya dan selalu ada padanya Al-Qur'an selalu menandaskan, bahwa akhlak itu baik atau buruknya akan memantul pada diri sendiri sesuai dengan pembentukan pembinaannya (Sukanto, 1994:14). Terkait materi akhlak, akun instagram@pelangiislam pun memknai bahwa baik buruknya seseorang dapat dilihat dari perilaku yang ia perlihatkan, maka dari itu penting adanya materi ini disampaikan, antara lain: 

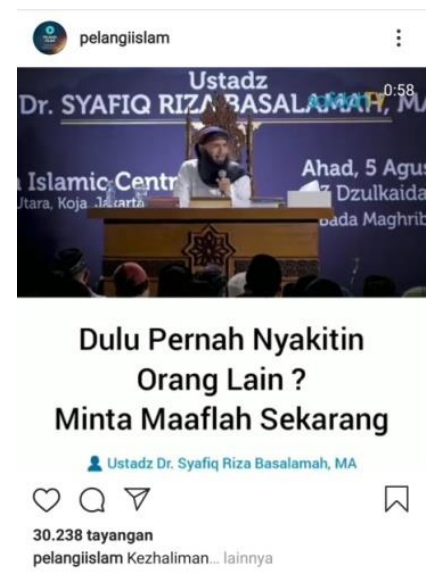

Sumber: Instagram @Pelangiislam

Gambar 3. Meminta Maaf Pada Orang Yang Pernah Disakiti

Kedzaliman seseorang pada saudaranya akan dipertanggung jawabkan di akhirat kelak, misalnya : menyakiti tubuh saudaranya, menggibahi saudaranya, tidak menunaikan hak-haknya, menjatuhkannya bahkan merampas hartanya. Maka kita berlindung kepada Allah agar dijauhkan dari berbuat dzalim dan dimudahkan dalam menunaikan setiap kewajiban kita. Karena bahaya pelaku dzalim dihari kiamat sangat besar. Dalam hukum qishash yang Allah SWT tegakkan, setiap perbuatan dzalim yang kita lakukan maka akan dibalas dengan yang setimpal.

Ustadz Syafiq menjelaskan bahwa pelaku dzalim akan mentransfer pahala kebaikan nya pada orang yang didzalimi, sebagai hukum qishashnya, dan apabila belum cukup, maka ia akan dapat transfer dosa dari yang di dzallimi, seperti sabda Rasulullah SAW, yang artinya :

"kelak kebaikan-kebaikannya akan diberikan kepada orang yang terdzalimi. Apabila amalan kebaikannya sudah habis diberikan sementara belum selesai pembalasan tindak kedzalimannya, maka diambillah dosa-dosa yang terdzalimi itu, lalu diberikan kepadanya. Kemudian diapun dicampakkan kedalam neraka (HR. Muslim).

Maka dari itulah kita harus senantiasa berbuat baik kepada saudara-saudara kita, apabila memang merasa telah melakukan kesalahan dimasa lampau maka bersegeralah meminta maaf kepadanya.

Materi syari'ah disini memiliki cakupan pembahasan yang begitu banyak antara lain pembahasan yang mencakup tentang shalat, zakat, puasa, haji dan lain sebagainya, sebagai contoh salah satu materi yang disajikan pada akun ini yaitu tentang masalah zakat. 


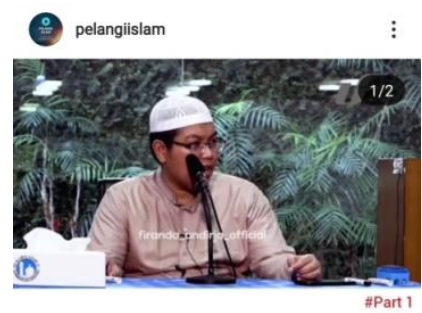

Lebih Aman Bayar Zakat

Fitrah Dengan $3 \mathrm{Kg}$ Beras

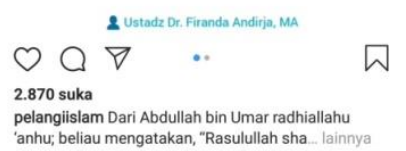

Sumber: Instagram @Pelangiislam

Gambar 4. Zakat Fitrah Dengan $3 \mathrm{Kg}$ beras

Dari Abdullah bin Umar RA, beliau mengatakan, "Rasulullah SAW mewajibkan zakat fitri, untuk lelaki dan wanita, orang merdeka maupun budak, berupa satu sha' kurma atau satu sha' gandum." (HR. Bukhari 1551 dan Muslim 232) Apa itu satu sha'? ustadz Firanda menjelaskan bahwa sha' adalah ukuran takaran bukan timbangan. Ukuran tkaran "sha" yang berlaku dizaman Rasulullah adalah sha' masyarakat madinah yang itu setar dengan 4 mud.

Satu mud adalah ukuran satu cakupan penuh dua telapak tangan normal yang digabungkan . dengan demikian, satu sha' adalah empat kali cakupan penuh dua telapak tangan normal yang digabungkan. Dengan melalui kajian para ulama (Lajnah Daimah, no. fatwa : 12572) telah melakukan penelitian bahwa satu sha' untuk beras dan gandum beratnya adalah $3 \mathrm{KG}$.

\section{Kriteria Vidgram Sebagai Sarana Media Dakwah Akun Pelangiislam (Editor Akun pelangiislam, 2 Juli 2019)}

Berdakwah merupakan salah satu perintah yang harus dikerjakan oleh seorang muslim, hal demikian dikarenakan dengan berdakwah maka kita sebagai seorang muslim telah melanjutkan perjuangan Rasulullah SAW untuk menyeru umat manusia untuk berada pada jalan yang diridhai oleh Allah SWT.

Berdakwah banyak disebutkan didalam Al-Qur'an yang secara garis besarnya yaitu perintah amar ma'ruf (menyeru kebaikan) dan nahyi munkar (melarang keburukan). Sebagaimana Firman Allah SWT, dalam Qur'an surat AnNahl ayat 125 :

"Berserulah (manusia) ke jalan Tuhanmu dengan hikmah dan pelajaran yang baik dan berikan bantahan menggunakan cara yang baik. Sesungguhnya 
Tuhanmu, Dialah yang lebih mengetahui tentang siapa yang tersesat dari jalanNya dan Dialah yang lebih mengetahui jalan orang-orang yang tersesat".

Dakwah dapat diartikan yaitu proses "menyeru" bukan "menyuruh" serta "mengajak" bukan "mengejak", sehingga dari sini kita dapat mengetahui bahwa kesuksesan berdakwah dihasilkan dari tata cara berdakwah yang baik, sesuai dengan tuntunan Qur'an dan Sunnah. Tata cara berdakwah sendiri tidak luput dengan yang namanya kriteria. Akun instagaram Pelangiislam dalam menyampaikan pesan dakwah selalu memperhatikan segala aspek didalamnya, salah satunya mengenai kriteria dakwah, yang mana diantaranya:

Pertama, lemah lembut dalam menyampaikan. Dalam mencapai tujuan dakwah, setiap pelaku dakwah memilki cara serta strateginya masing-masing. Akan tetapi dirasa sangat perlu dalam penyampaian pesan dakwah, para pelaku dakwah ditunutut menggunakan tutur kata yang baik, santun serta lemah lembut, dikarenakan beragamnya sifat manusia sehingga dikahwatirkan dapat mengurangi keefektifan dakwah tersebut, sebagaimana firman Allah SWT, dalam Quran Surat Ali-Imran ayat 159:

"Maka dengan rahmat dari Allah lah kamu berlaku lemah lembut kepada mereka, sekiranya kamu bersikap keras lagi berhati kasar, tentulah mereka menjauhkan diri dari sekelilingmu. Maka dari itu maafkanlah mereka dan mohonkanlah ampun bagi mereka dan bermusyawarahlah dengan mereka dalam urusan itu. Kemudian apabila kamu telah membulatkan tekad, maka bertakwalah kepada Allah, sesungguhnya Allah menyukai orang-orang yang bertawakal kepadanya".

Dalam ayat tersebut sudah dapat dijelaskan, untuk meraih tujuan dakwah atau melakukan dakwah yang efektifdan efisien, maka berlemah lembutlah dalam menyampaikan pesan dakwah, sehingga mad'u disekelilingmu dapat mengerti, memahami dan memiliki rasa ingin tahu yang tinggi terhadap pesan dakwah yang disampaikan tersebut.

Kedua, mempermudah tidak mempersulit. Dalam dakwah sendiri, pelaku dakwah dituntut untuk menyampaikan dakwah dengan kadar kemampuannya sehingga dapat diterima oleh objek dari dakwah tersbut (mad'u). Sebagaimana disebutkan didalam Hadist Riwayat Bukhari :

"Sesungguhnya agama itu mudah, dan sekali-kali tidaklah seseorang memperberat agama melainkan akan dikalahkan, dan (dalam beramal) hendaklah pertengahan (yaitu tidak melebihi dan tidak mengurangi), bergembiralah kalian, serta mhonlah pertolongan (didalam ketaatan kepada Allah) dengan amal-amal kalian pada waktu kalian bersemangat dan giat". (HR. Bukhari)

dengan demikian dakwah yang ingin disampaikan haruslah dikemas dengan bahasan yang ringan dan mudah. Dengan pegemasan dakwah yang ringan dan 
Taqdirul. A.Y, M. Aliyudin, Shodiqin. A.

mudah, hal ini menjadikan pemicu agar pesan dakwah dapat diterima diseluruh kalangan masyarakat.

Ketiga, memberikan kesadaran. Tujuan berdakwah pada dasarnya adalah untuk meberikan kesadaran kepada umat manusia, terutama dan yang paling utama menyadarkan manusia agar kembali atau senantiasa berada dijalan yang benar, dijalan yang lurus dan dijalan yang diridhai oleh Allah SWT. Manusia adalah tempat salah dan lupa, maka dari itu dakwah yang tepat khususnya dalam akun dakwah ini adalah pesan-pesan yang dapat mengingatkan serta selalu meyadarkan manusia akan keberadaan Tuhannya, Allah SWT.

Keempat, tidak provokatif. Dakwah yang baik adalah dakwah yang bersumber dari Al-Qur'an dan Sunnah, akan tetapi diera media sosial ini terkadang banyak para pelaku dakwah yang terkesan provokatif, sehingga menimbulkan kesalahpahaman oleh yang mendengarkan serta menimbulkan perdebatan diantara sesama umat muslim itu sendiri. Sejatinya Islam adalah agama yang rabmatan lil 'alamin, sehingga sudah seharusnya dakwah yang disampaikan dapat menyadarkan serta memberi kenyamanan di seluruh elemen masyarakat.

Kelima, memiliki pendasaran yang kuat. Kriteria dakwah yang terakhir adalah terkait pendasaran yang kuat. Pendasaran yang kuat adalah segala sesuatu yang bersumber dari Al-Qur'an dan Hadist. Tanpa adanya dasar yang kuat, mad'u yang mendengarkan dikhawatirkan malah memiliki keraguan atas pesan dakwah yang disampaikan, karena manusia tentu membutuhkan alasan yang mampu dimengerti dan menggugah dirinya, maka dalam akun ini pengemasan dakwah dilakukan dengan sebaik mungkin dengan disertakan dasar-dasar yang kuat, sehingga tidak menimbulkan keraguan dibenak para mad'unya.

Kelima kriteria ini yang menjadi dasar dalam penyampain pesan dakwah melalui fitur vidgram akun instagram Pelangiislam tersebut. Dengan kriteria yang dimiliki, dakwah dapat dilakukan secara efektif dan efisien, serta mad'u yang menerima pesan dakwah dapat mengerti, memahami serta dapat menyampaikan nya kembali kepada orang lain, karena sebaik-baiknya manusia adalah orang yang bermanfaat bagi manusia lainnya.

\section{PENUTUP}

Kemajuan dibidang teknologi dan informasi khususnya media sosial setidaknya memberikan manfaat serta peluang yang baik bagi para pelaku dakwah. Pelaku dakwah dituntut untuk lebih cermat dalam memanfaatkan media sosial sebagai salah satu sarana media dakwah. Instgram merupakan salah satu jejaring sosial yang sedang digandrungi oleh sebagian besar masyarakat, terkhusus pada kalangan remaja dan anak muda. Dengan berbagai fitur yang disediakan instagram menjadi jejaring sosial yang amat sangat mudah digunakan dalam berinteraksi didunia maya. Fitur vidgram merupakan salah satu fitur unggulan yang dimiliki oleh instgram, dengan durasi video maksimal 60 detik, para 
pengguna dapat memanfaatkan nya untuk berbagai hal yang mana salah satunya adalah untuk menyampaikan pesan dakwah. Penelitian dengan judul vidgram sebagai sarana media dakwah terhadap akun Instagram Pelangiislam dapat ditarik kesimpulan sebagai berikut :

Pertama, Penggunaan Vidgram Sebagai Sarana Media Dakwah Oleh Akun Instagram Pelangiislam. Akun Pelangiislam menggunakan fitur vidgram dengan dengan cara yang terbilang sederhana namun berkualitas. Tanpa ada ketentuan yang terperinci pada awal mulanya, akun Pelangiislam memulai dengan tahapan pemilihan video kajian dakwah keislaman yang mana didalamnya terdapat pemilihan da'i / pelaku dakwah serta materi dakwahnya, setelah melakukan pemilihan tersebut akun Pelangiislam memilih dan memilah bagian terpenting pada video kajian dakwah keislaman tersebut sehingga menjadi sebuah video dengan durasi maksimal 60 detik. Tidak hanya itu, untuk menghasilkan dakwah yang menarik dengan menggunakan fitur ini, akun dakwah.vidgram mengemas video tersebut dengan memberikan thumbnail serta logo akun tersebut sehingga terlihat menarik dan berkualitas, yang mana hal ini ternyata meningkatkan minat para pengguna instagram untuk mlihat serta mendengarkan kajian dakwah keislaman di jejaring sosial instagram akun Pelangiislam.

Kedua, Materi Dakwah Akun Pelangiislam. Materi dakwah yang disajikan oleh akun Pelangiislam merupakan sebuah produksi ulang dari materi yang telah melewati proses / tahap editing tanpa menghilangkan sumber awal materi tersebut. Sebagai contoh, materi dakwah yang ia dapat berduaasi 1 jam, maka karena media yang digunakan berbeda, akun Pelangiislam memotong serta memilah poin-poin penting yang akan disampaikan dan menambahkan berbagai komponen, seperti thumbnail, tagar, caption sebagai pelengkap dan penjelas pesan dakwah tersebut. Materi dakwah yang disampaikan oleh akun Pelangiislam berupa videogram berdurasi 60 detik yang dikemas menggunakan gaya akun tersebut. Videogram yang disampaikan dapat dikategorikan kepada 3 materi bahasan yaitu Akidah, Akhlak dan Syari'ah. Tidak ada penekanan terhadap materi tertentu, karena seluruh materi atau ilmu tentang keislaman (agama islam) dirasa amat sangat perlu disampaikan sebagai pengetahuan manusia (umat islam) untuk keberlangsungan hidupnya dan demi memperoleh kebahagiaan hidup di dunia dan di akhirat.

Ketiga, Kriteria Dakwah Vidgram Pada Akun Instagram Pelangiislam. Demi meraih kesuksesan dakwah maka sangat diperlukan yang dinamakan tata cara berdakwah, dakwah yang efektif dan efisien dihasilkan dari tata cara berdakwah yang baik, sesuai dengan tuntunan Qur'an dan Sunnah. Tata cara berdakwah sendiri tidak luput dengan yang namanya kriteria. Akun instagram Pelangiislam dalam menyampaikan pesan dakwah selalu memperhatikan segala aspek didalamnya, salah satunya mengenai kriteria dakwah, adapun kriteria dakwah vidgram yang dijadikan acuan sebagai salah satu cara untuk meraih 
Taqdirul. A.Y, M. Aliyudin, Shodiqin. A.

kesuksesan dalam berdakwah di instagram oleh akun nya tersebut, yaitu : lemah lembut dalam menyampaikan, mempermudah tidak mempersulit, memberikan kesadaran, tidak provokatif, dan memiliki pendasaran yang kuat

Kelima kriteria ini yang menjadi dasar dalam penyampain pesan dakwah melalui fitur vidgram akun instagram Pelangiislam tersebut. Dengan kriteria yang dimiliki, dakwah dapat dilakukan secara efektif dan efisien, sehingga mad'u dapat mengerti, memahami serta dapat mengamalkan pesan dakwah tersebut.

\section{DAFTAR PUSTAKA}

Atmoko, D. B. (2012). Instagram. Jakarta: Media Kita.

Aziz, M. A. (2004). Imu Dakwah. Jakarta: Prenadan Media.

Dulwahab, E. (2016). Rebranding Dakwah Di Media Televisi Dalam Anisa (Aktualisasi Nuansa Ilmu Dakwah), 15(2): 1410-5705.

Enjang, A. 2009. Dasar Dasar Imu Dakwah. Bandung: Tim Widya Padjadjaran.

Fakhruroji, M. (2017). Dakwah Di Era Media Baru. Bandung: Simbiosa Rekatama Media

Nasrullah, R. (2015). Media Sosial Perspektif Komunikasi Budaya dan Sosioteknologi. Bandung: Simbiosa Rekatama.

Saerozi. (2013). Ilmu Dakwah. Yogyakarta: Penerbit Ombak.

Sukayat, T. (2009). Quantum Dakwah. Jakarta: Rineka Cipta.

Sukayat, T. (2015). Ilmu Dakwah. Bandung: Simbiosa Rekatama Media.

Muhaemin, E. (2017). Dakwah Digital Akademisi Dakwah Dalam Ilmu Dakwah: Academic Journal For Homiletic Studies 11(2), 341-356.

Zahra, U. F. (2016). Media Sosial Instagram Sebagai Media Dakwah Dalam Tabligh: Jurnal Komunikasi dan Penyiaran Islam 1(2), 60-88. 